\title{
MILK PRODUCTION, SOME RUMEN PARAMETERS AND FEED UTILIZATION EFFICIENCY OF LACTATING GOATS FED RATIONS CONTAINING BERSEEM SILAGE AND THEIR MIXTURE WITH BARELY OR MILLET X NAPIER GRASS HYBRID. \\ EI-Emam, G.I.; M.R.M.Saleh;M.E.El-Kholany; Hoda.M.El-Hosseiny and S. B. Mehany \\ Animal Production Research Institute, Agricultural Research Center, Dokki, Giza, Egypt.
}

\begin{abstract}
The effect of using berseem silage and its mixtures with barely or millet $x$ napier grass hybrid in diets of lactating goats on their performance for milk production and feed conversion efficiency was studied. Eighteen Zaraibi does with average body weight of $40.0 \mathrm{~kg}$ were divided randomly into three equal groups (6 in each group). All animals were fed concentrate feed mixture (CFM) to cover $40 \%$ of requirements recommended by $N R C$ (1981). Besides ad libitum silage supplement, where berseem silage offered to group $1\left(\mathrm{G}_{1}\right)$, silage made of $50 \%$ berseem $-50 \%$ barley to group 2 $\left(\mathrm{G}_{2}\right)$ and silage made of $50 \%$ berseem $-50 \%$ millet $\times$ Napier grass hybrid to group 3 $\mathrm{G}_{3}$. The feeding trails lasted 14 weeks. The obtained results showed that the crude protein $(\mathrm{CP})$ and ash of berseem silage were higher (14.61 and $12.31 \%$, respectively) than the other silages. But, the crude fiber (CF), ether extract (EE) and nitrogen free extract (NFE) were lower in berseem silage $(28.84,2.29$ and $41.95 \%$, respectively) compared with their mixtures with barely or millet $x$ napier grass hybrid. The daily feed intake as $\mathrm{g} / \mathrm{h}, \% B W$ and $\mathrm{g} / \mathrm{h} \mathrm{w}^{0.75}$ was increased with mixture silage $\left(\mathrm{G}_{2}\right.$ and $\mathrm{G}_{3}$ ) compared with berseem silage alone $\left(\mathrm{G}_{1}\right)$. The effect of the experimental rations on daily water consumption was not noticeable.

As for ruminal parameters, ammonia- $N$ concentration was significantly $\left(P_{<}\right.$ 0.05 ) higher with berseem silage $\left(G_{1}\right)$ compared with $G_{2}$ and $G_{3}$. But, ruminal total VFA's concentrations and microbial protein were significantly $(P<0.05)$ lower with $G_{1}$ compared with $\mathrm{G}_{2}$ and $\mathrm{G}_{3}$ during 2 and $4 \mathrm{hrs}$ post-feeding. The effect of the tested rations on most blood parameters was not significant $(P<0.05)$.

As for milk production, the obtained data showed that milk yield of dairy goats was significantly $(P<0.05)$ decreased with $G_{1}(1.339 \mathrm{~kg} / \mathrm{h} / \mathrm{d})$ compared with $\mathrm{G}_{2}$ $(1.601 \mathrm{~kg} / \mathrm{h} / \mathrm{d})$ and $\mathrm{G}_{3}(1.550 \mathrm{~kg} / \mathrm{h} / \mathrm{d})$. Milk composition as fat, protein, lactose, total solids, solids non fat and ash for the three treatments were fluctuated without significances. Accordingly, the feed conversion efficiency based on DM and $\mathrm{CP}$, was better with $\mathrm{G}_{2}$ ( 0.901 and 0.125 , respectively) and $\mathrm{G}_{3}(0.911$ and 0.123 , respectively) compared with berseem silage alone, $\mathrm{G}_{1}(1.01$ and 0.145 , respectively).

Keywords: Lactating Zaraibi goats- rumen parameters - blood profile - milk yield feed conversion.
\end{abstract}

\section{INTRODUCTION}

In Egypt, feed and food production is highly associated, since increasing one of them will lead to decrease the other due to competition on limited cultivated area of berseem will lead to decrease the cultivated area of wheat (Eweedah et al. 2007). 


\section{El-Emam G. I. et al.}

Therefore, searching for unclassical plants or new sources of green crops to be used in animal feeding is vivible route to overcome this problem and would help in raising more animals and reducing the feed costs (Ahmed et al., 2012). Most green forages in summer season are grasses such as sorghum, Sudan grass, millet, napier grass and teosinte which have low protein content. So, it needs protein source as concentrate or legume forages to be complete rations. High yielding and high quality legume- grass mixture play an important part in forage - animal production (Mooso and Wedin, 1990). Attempts were carried out to introduce new legumes as cowpea, Sesbania and Kochia indica ( Gabra et al., 1991, Soliman et al. 1997 and Ahmed et al., 2001) or grasses as millet $x$ napier grasses hybrid (Zeidan and Geweifel, 1997) in animal feeding. On the other side, some practical studies were carried out to utilization some mixtures of legumes and grasses in ruminant feeding such as berseem with triticale (Haggag et al. 2000 and Ahmed et al., 2013) and cowpea with millet $x$ napier grass hybrid (Ibrahim et al. 2008). The aim of the present study was to investigate the effect of feeding berseem silage and its mixtures with barley or millet $x$ napier grass hybrid on milk production and feed conversion efficiency of lactating Zaraibi goats. Some rumen parameters and blood profile were also studied.

\section{MATERIALS AND METHODS}

The study was conducted at El-Serw Experimental Station, Animal Production, Research Institute, Agricultural research center, Ministry of Agriculture, Egypt. Eighteen lactating Zaraibi does, averaged $40.0 \mathrm{~kg}$ live body weight, were divided into three feeding treatments (6 each). Each group was housed in a semi-roofed barn $(4 \times 3 \times 5)$. The animals were weighed at the beginning then biweekly. Feeding the experimental rations lasted 14 weeks. Zaraibi goats in all groups, were fed restricted amount of concentrate feed mixture (CFM) to cover $40 \%$ of the total protein requirements recommended by NRC (1981) for lactating goats. Yet, a combination of different silages was fed ad libitum. Accordingly, rations tested were, CFM+ berseem (trifolium alexandarinum) ( $1^{\text {st }}$ cut) silage $\left(\mathrm{G}_{1}\right)$, CFM - 50\% berseem- $50 \%$ barely (Hordeum vulgare) silage $\left(\mathrm{G}_{2}\right)$ and CFM $+50 \%$ berseem- $50 \%$ millet (Pennisetum maximum) $\mathrm{x}$ napier grass (Pennisetum purpureum) hybrid silage $\left(G_{3}\right)$. The forages (berseem / or its mixtures with barely or millet $x$ napier grass hybrid) were mechanically chopped then wilted for 24 to $48 \mathrm{hrs}$ before ensiling to diminish the moisture content to about $70 \%$. Ensiling was done using cement pits $(1.5 \times 4.0 \times 1.0 \mathrm{~m})$, which were tightly covered by plastic sheets followed by approximately $20 \mathrm{~cm}$ soil layer to keep an aerobic condition. The ensiling was lasted for 40 days then samples were taken to test for the physical and fermentative characteristics. Berseem silage was prepared by adding $3 \%$ molasses, on fresh basis, while mixture silages in $G_{2}$ and $\mathrm{G}_{3}$ prepared without any additives according to Ahmed et al. (2001 and 2013). The chemical analysis of CFM and different types of silages is presented in Table 1. 
The rations were offered twice daily at 8 am and $4 \mathrm{pm}$. Samples of feed were analyzed according to the procedures of A.O.A.C. (1995). Water was available at all times and was measured as average for each group.

The daily milk yield was recorded for each goat. Representative milk samples (about $0.5 \%$ of total milk produced) were taken once biweekly from each goat, from the morning and evening milking of the same day. Then the samples were compared and analyzed for total solid (TS), fat, protein, solid non fat (SNF) and ash according to Ling procedures (1963), while milk lactose was calculated by differences.

Rumen fluid samples were taken from 3 animals of each experimental group using stomach tube before feeding (0 time) and at 2, 4, 6 and $8 \mathrm{hrs}$ post-feeding. The samples were filtered through 3 layers of gauze and immediately subjected to the determination of $\mathrm{pH}$ value by $\mathrm{pH}$ meter. Ammonia nitrogen ( $\mathrm{NH} 3-\mathrm{N}$ ) concentration was measured according to the method of Conway (1957), total volatile fatty acids was determined according to the technique described by Warner (1964), whereas microbial protein was determined according to Schultz and Schultz (1970).

Blood samples were collected from the jugular vein once before feeding ( 3 animals from each treatment) at the end of feeding trials. Blood samples were centrifuged at $4000 \mathrm{rpm}$ for 20 minutes. Part of the separated serum was directed to enzymes activity determination, while the other part was stored frozen at $-20 c^{0}$ till the biochemical analysis. Commercial kits were used for colorimetric biochemical determinations.

Data was statistically analyzed using SAS (2003). The significant differences among means were assigned according to Duncan (1955).

\section{RESULTS AND DISCUSSION}

\section{Chemical composition :}

The chemical analysis of different types of silage as shown in Table 1 explained that dry matter (DM) of $50 \%$ berseem $-50 \%$ barely silage was lower than in berseem silage or $50 \%$ berseem $50 \%$ millet $x$ napier grass hybrid. Crude protein (CP) in berseem silage was higher (14.61\%) than in the other silages. On the contrary, the percentages of crude fiber (CF), ether extract (EE) and nitrogen free extract (NFE) of berseem silage were lower than their mixture with barely or millet $x$ napier grass hybrid. But, organic matter (OM) of three silages were nearly similar (ranged from 87.69 to 88.70 $\%)$. The chemical composition of the tested silages was nearly similar with data obtained by Ahmed et al (2013) with berseem silage, Ibrahim et al (2008 and 2012) with millet $x$ napier grass hybrid -cowpea mixture and McCartney and Vaage (1994) with barely silage.

Generally, the chemical composition of legume and grass (Gabra et al., 1991, Khinizy et al., 1997 and Soliman and Haggag, 2002., showed that cowpea had a high content of CP and low content of CF and NFE than grasses (Sudan grass, sorghum, napier grass and millet). However, there are many factors affecting chemical composition as species and varieties of 


\section{El-Emam G. I. et al.}

forages, soil, fertilization, subsequent cuts, age, cuts and environmental condition (Gabra et al., 1991 Van Soest, 1996 and Haggag et al., 2000).

\section{Feed intake and water consumption :}

The daily DM intake of dairy goats are presented in Table 2 . The total DM intake as \% BW or $\mathrm{g} / \mathrm{kg}$ w $^{0.75}$ decreased with $\mathrm{G}_{1}$ (3.39 and 85.15, respectively) compared with $\mathrm{G}_{2}$ (3.59 and 90.36 , respectively) and $\mathrm{G}_{3}$ (3.52 and 88.58, respectively). This increase in $D M$ intake with mixture silage $\left(G_{2}\right.$ and $\mathrm{G}_{3}$ ) was observed also by El-Kholany (2004) and Ibrahim et al. (2012) using mixture of silages in Zaraibi goats and Rahmani sheep, respectively. In the sametime, the ratio of roughage to concentrate tended to increase with both of silage mixture compared with berseem silage alone (60 :40). Generally, the increased roughages intake (silage) gave positive evidence that silage was of good quality as reported by Ahmed et al (2001 and 2013) with lactating goats.

The average daily water consumption of lactating Zaraibi goats fed the tested experimental rations is summarized in Table 2. The differences among the three groups in water consumption $\left(\mathrm{L} / \mathrm{h}\right.$ and $\left.\mathrm{ml} / \mathrm{kgw}^{0.82}\right)$ were not noticeable. However, the highest value of daily water consumption $(\mathrm{ml} / \mathrm{g}$ DM intake) was recorded with $\mathrm{G}_{1}$ (2.94) while $\mathrm{G}_{2}$ had recorded the lowest value (2.76). Generally, the quantity of daily water consumption in present study is nearly similar to those obtained by Soliman et al. (2010) on growing Zaraibi goats (ranged from 2.22 to $3.30 \mathrm{ml} / \mathrm{g}$ DM intake) and Ahmed et al. (2013) on lactating Zaraibi goats (ranged from 2.82 to $3.06 \mathrm{ml} / \mathrm{g}$ DM intake).

\section{Rumen parameters :}

Rumen parameters are presented in Tables 3 and 4. The maximum $\mathrm{pH}$ values were noticed pre-feeding ( 0 time) while the minimum values were observed at $4 \mathrm{hrs}$ post-feeding then it tended to increase again at $8 \mathrm{hrs}$ postfeeding for all dietary treatments. In the sametime, the effect of the tested rations on $\mathrm{pH}$ values was not significant. Similar results were observed by Ahmed et al. (2013).

Ruminal ammonia- $\mathrm{N}$ concentration was greatly higher post-feeding than before feeding. The same trend was observed by Ahmed et al (2001) and Ibrahim et al. (2012). The highest values of ruminal ammonia- $N$ were recorded with $\mathrm{G}_{1}$ (berseem silage) and the lowest values were detected with $\mathrm{G}_{3}$ (berseem- millet $\mathrm{x}$ napier grass hybrid silage) and the differences were significant at 2 and $4 \mathrm{hrs}$ post-feeding only. This increase in ruminal ammonia- $N$ concentration in $\mathrm{G}_{1}$ may be due to the high content of $\mathrm{CP}$ in berseem silage as reported earlier in Table1. The same results were observed by Ahmed et al.( 2013) with using berseem silage and its mixtures with some grasses in goats rations.

The average concentrations of total VFA's post-feeding ( 4 and $8 \mathrm{hrs}$ ) in the rumen were significantly decreased with $\mathrm{G}_{1}(12.0$ and $10.77 \mathrm{~m} \mathrm{Eq} /$ $100 \mathrm{ml}$, respectively) compared with $\mathrm{G}_{2}(13.33$ and $11.90 \mathrm{~m} \mathrm{Eq} / 100 \mathrm{ml}$, respectively) and $\mathrm{G}_{3}$ (13.07 and $11.50 \mathrm{mEq} / 100 \mathrm{ml}$, respectively). Similar findings were shown by Haggag et al. (2002) and El-Kholany (2004) using mixture forage and silage in Rahmani sheep and Zaraibi goats, respectively. 
Table 4 illustrates the data collected for microbial protein of goats under investigation. Ruminal microbial protein was not significantly different among three treatments at zero time and was significantly $(P<0.05)$ higher with $G_{2}$ than of berseem silage $\left(G_{1}\right)$ at 4 and 8 hrs post-feeding. But, $G_{3}$ recorded the medium values. This positive effect of mixture silage on ruminal microbial protein was observed also by Shehata et al. (2001), Ibrahim et al.(2012) and Ahmed et al. (2013) in the rumen of bucks, lambs and lactating does, respectively.

\section{Blood profile :}

Values of some blood parameters (Table 5) explained that there were no significant differences among three rations for red blood cells (RBC's), cholesterol, total protein, creatinine and calcium, while serum urea-N of $\mathrm{G}_{1}$ was significantly higher than $\mathrm{G}_{2}$ and $\mathrm{G}_{3}$. The higher value of serum urea-N of $\mathrm{G}_{1}$ (berseem silage) may be due to higher level of ammonia- $\mathrm{N}$ in the rumen as reported also by lbrahim et al. (2008). Serum AST activities showed some fluctuation among groups, ranging from 73.33 to $75.67 \mathrm{u} / \mathrm{l}$. Both ALT and ALP activities were higher with $\mathrm{G}_{1}(22.0$ and $112.0 \mathrm{u} / \mathrm{l}$, respectively) compared with the other groups and the differences were not significant. The effect of the experimental rations on serum glucose was significant. In the sametime, serum phosphorus (inorganic) was significantly higher with mixture of silages $\left(G_{2}\right.$ and $\left.G_{3}\right)$ compared with berseem silage alone $\left(G_{1}\right)$. This is in line with the findings of Ahmed et al (2001). Generally, the obtained values are within the normal physiological ranges reported by Jain (1986) and Keneko (1989) for healthy goats and in the line with findings of Gabr et al. (1999), El-Kholany (2004) and Ibrahim et al . (2008 and 2012) who used mixture of silage (or forage) in small ruminant rations.

Milk yield and its composition :

Data presented in Table 6 and Figure 1 showed average milk yield and its composition for the three treatments. The differences in milk yield were significantly $(\mathrm{P}<0.05)$ among the tested experimental rations. The daily milk yield had the highest values with $\mathrm{G}_{2}(1.601 \mathrm{~kg} / \mathrm{d})$ followed by $\mathrm{G}_{3}(1.550$ $\mathrm{kg} / \mathrm{d}$ ) and the lowest value was recorded with $\mathrm{G}_{1}$. The same positive results of silages mixture (legume- grass) on daily milk yield by dairy goats were reported by El-Kholany (2004) and Ahmed et al (2013).

As regard to milk composition (Table 6), the data indicated that the effect of experimental treatments on milk composition as fat, protein, total solids, SNF and ash was fluctuated between them. However, the differences of milk composition among three groups were not significant. The values of milk chemical composition were nearly similar with values obtained by Ahmed et al. (2001) and Ibrahim et al. (2008) on Zaraibi goats with little differences due to the individual differences among goats and feeding system.

Generally, yields of fat and protein were significantly higher with mixture of silages $\left(G_{2}\right.$ and $\left.G_{3}\right)$ compared with berseem silage alone $\left(G_{1}\right)$ as shown in Table 6. These results were related to the average milk yield as reported earlier in the present study and by Ahmed et al.(2001). 


\section{El-Emam G. l. et al.}

\section{Feed utilization :}

Data of average feed intake and average milk yield during experimental period as well as feed conversion efficiency of the dairy Zaraibi goats are summarized in Table 7. The data indicated that the average milk yield recorded the highest value $(1.601 \mathrm{~kg} / \mathrm{h} / \mathrm{d})$ with $\mathrm{G}_{2}$ followed by $\mathrm{G}_{3}(1.550 \mathrm{~kg} / \mathrm{h} / \mathrm{d})$ and lastly, $\mathrm{G}_{1}$ which recorded the lowest value $(1.339 \mathrm{~kg} / \mathrm{h} / \mathrm{d})$ and the differences were significant. Thus, the feed conversion calculated as $\mathrm{DM}$ and $\mathrm{CP}$ (intake / milk yield) was better in $\mathrm{G}_{2}$ ( 0.901 and 0.125, respectively) and $\mathrm{G}_{3}\left(0.911\right.$ and 0.123 , respectively) compared with $\mathrm{G}_{1}(1.01$ and 0.145 , respectively). Similar results were observed by El-Kholany (2004) and Ahmed et al. (2013) using mixture of silages for dairy Zaraibi goats. In recent study, Ibrahim et al. (2012) observed that feed conversion efficiency based on DM and TDN was better with Rahmani sheep fed mixed silage (legume- grass) than those fed cowpea or millet $x$ napier grass hybrid alone. Generally, the obtained values of feed conversion are within the normal range given by Ahmed et al. (2001 and 2008) and Ibrahim et al. (2008).

Table 1.Chemical composition (\% on dry matter basis) of tested ingredients.

\begin{tabular}{|c|c|c|c|c|}
\hline \multirow[t]{2}{*}{ Items } & \multicolumn{3}{|c|}{ Silages } & \multirow[b]{2}{*}{$\begin{array}{l}\text { Concentrate } \\
\text { feed mixture }\end{array}$} \\
\hline & $\begin{array}{c}100 \% \\
\text { berseem }\end{array}$ & $\begin{array}{c}50 \% \text { berseem } \\
50 \% \text { barely }\end{array}$ & $\begin{array}{c}50 \% \text { berseem } 50 \% \\
\text { millet x napier grass } \\
\text { hybrid }\end{array}$ & \\
\hline DM & 29.50 & 28.63 & 30.15 & 91.00 \\
\hline \multicolumn{5}{|c|}{ Chemical analysis ( $\%$ on DM basis) } \\
\hline $\mathrm{OM}$ & 87.69 & 88.70 & 88.0 & 93.95 \\
\hline $\mathrm{CF}$ & 28.84 & 29.35 & 30.01 & 15.50 \\
\hline $\mathrm{CP}$ & 14.61 & 13.75 & 13.27 & 14.0 \\
\hline EE & 2.29 & 2.57 & 2.41 & 3.15 \\
\hline NFE & 41.95 & 43.03 & 42.31 & 61.30 \\
\hline Ash & 12.31 & 11.30 & 12.00 & 6.05 \\
\hline
\end{tabular}

${ }^{*}$ Concentrate feed mixture ( CFM) consists of $36 \%$ yellow corn, $30 \%$ undecortecated cotton seed, $27 \%$ wheat bran, $3.0 \%$ molasses, $2.5 \%$ limestone, $1 \%$ common salt and $0.5 \%$ minerals mixture.

Table 2. Average feed intake ${ }^{\star}$ and water consumption by lactating Zaraibi goats fed the tested experimental rations.

\begin{tabular}{|c|c|c|c|}
\hline \multirow[t]{2}{*}{ Items } & \multicolumn{3}{|c|}{ Groups* $^{*}$} \\
\hline & $\mathbf{G}_{1}$ & $\mathbf{G}_{2}$ & $\mathbf{G}_{3}$ \\
\hline \multicolumn{4}{|c|}{ Daily DM intake during experimental period } \\
\hline From CFM & 535 & 549 & 545 \\
\hline From silage & 813 & 894 & 867 \\
\hline Total DM intake & 1348 & 1443 & 1412 \\
\hline DM intake, \% BW & 3.39 & 3.59 & 3.52 \\
\hline DM intake, $\mathrm{g} / \mathrm{kgw}^{0.75}$ & 85.15 & 90.36 & 88.58 \\
\hline Roughage :concentrate $(\mathrm{R} / \mathrm{C})$ ratio & $60: 40$ & $62: 38$ & $61: 39$ \\
\hline \multicolumn{4}{|l|}{ Daily water consumption } \\
\hline $\mathrm{L} / \mathrm{h} / \mathrm{d}$ & 3.96 & 3.98 & 4.09 \\
\hline $\mathrm{Ml} / \mathrm{kg} \mathrm{BW}$ & 100 & 99 & 102 \\
\hline $\mathrm{Ml} / \mathrm{kg} \mathrm{W}^{0.82}$ & 250 & 249 & 257 \\
\hline MI/g DM intake & 2.94 & 2.76 & 2.90 \\
\hline
\end{tabular}

${ }^{*}$ Group feeding 
Table3.Effect of the experimental rations on rumen $\mathrm{pH}$ values and ammonia-N concentrations of dairy goats.

\begin{tabular}{|l|c|c|c|c|}
\hline Items & Hours & \multicolumn{3}{|c|}{ Groups } \\
\cline { 2 - 5 } & & $\mathbf{G}_{1}$ & $\mathbf{G}_{\mathbf{2}}$ & $\mathbf{G}_{3}$ \\
\hline pH values & 0 & $7.07 \pm 0.09$ & $7.00 \pm 0.10$ & $7.10 \pm \mathbf{0 . 0 6}$ \\
\cline { 2 - 5 } & 2 & $6.63 \pm 0.03$ & $6.60 \pm 0.06$ & $6.57 \pm 0.03$ \\
\cline { 2 - 5 } & 4 & $6.50 \pm 0.06$ & $6.40 \pm 0.06$ & $6.43 \pm 0.03$ \\
\cline { 2 - 5 } & 6 & $6.60 \pm 0.06$ & $6.53 \pm 0.03$ & $6.57 \pm 0.03$ \\
\cline { 2 - 5 } & 8 & $6.67 \pm 0.07$ & $6.57 \pm 0.03$ & $6.63 \pm 0.03$ \\
\hline Ammonia-N ( mg/100 ml) & 0 & $17.13 \pm 0.18$ & $17.00 \pm 0.23$ & $16.87 \pm 0.35$ \\
\cline { 2 - 5 } & 2 & $22.40 \pm \mathbf{0 . 1 2}$ & $21.73 \pm 0.13^{\mathbf{a b}}$ & $21.00 \pm \mathbf{0 . 1 2}$ \\
\cline { 2 - 5 } & 4 & $23.60 \pm 0.12^{\mathbf{a}}$ & $22.80 \pm 0.20^{\mathbf{b}}$ & $22.13 \pm 0.18^{\mathbf{b}}$ \\
\cline { 2 - 5 } & 6 & $22.20 \pm 0.12$ & $21.67 \pm 0.27$ & $21.33 \pm \mathbf{0 4 0}$ \\
\cline { 2 - 5 } & 8 & $21.40 \pm \mathbf{0 . 3 1}$ & $21.00 \pm \mathbf{0 . 4 6}$ & $20 . \mathbf{8 0} \pm \mathbf{0 . 4 0}$ \\
\hline
\end{tabular}

Means in the same row with different superscripts differ significantly at $P<0.05$.

Table 4. Effect of the experimental rations on ruminal total volatile fatty acids (TVF's) and microbial protein content of dairy goats.

\begin{tabular}{|l|c|c|c|c|}
\hline \multirow{2}{*}{ Items } & Hours & \multicolumn{3}{|c|}{ Groups } \\
\cline { 2 - 5 } & & $\mathbf{G}_{1}$ & $\mathbf{G}_{\mathbf{2}}$ & $\mathbf{G}_{3}$ \\
\hline \multirow{3}{*}{$\begin{array}{l}\text { Total VFA's ( } 100 \mathrm{ml} \text { ) } \\
\end{array}$} & 0 & $8.87 \pm 0.19$ & $9.10 \pm 0.20$ & $8.93 \pm 0.22$ \\
\cline { 2 - 5 } & 4 & $12.00 \pm 0.17^{\mathrm{b}}$ & $13.33 \pm 0.22^{\mathrm{a}}$ & $13.07 \pm 0.13^{\mathrm{a}}$ \\
\cline { 2 - 5 } & 8 & $10.77 \pm 0.15^{\mathrm{b}}$ & $11.90 \pm 0.10^{\mathrm{a}}$ & $11.50 \pm 0.12^{\mathrm{a}}$ \\
\hline \multirow{2}{*}{$\begin{array}{l}\text { Microbial protein } \\
\text { (g/100ml) }\end{array}$} & 0 & $0.353 \pm 0.02$ & $0.347 \pm 0.01$ & $0.340 \pm 0.02$ \\
\cline { 2 - 5 } & 4 & $0.560 \pm 0.016^{\mathrm{b}}$ & $0.593 \pm 0.01^{\mathrm{a}}$ & $0.583 \pm 0.01^{\mathrm{a}}$ \\
\cline { 2 - 5 } & 8 & $0.463 \pm 0.016^{\mathrm{b}}$ & $0.500 \pm 0.01^{\mathrm{a}}$ & $0.493 \pm 0.01^{\mathrm{a}}$ \\
\hline
\end{tabular}

Means in the same row with different superscripts differ significantly at $P<0.05$.

Table 5 . Blood profile of dairy Zaraibi goats as affected by different experimental rations.

\begin{tabular}{|l|c|c|c|}
\hline \multirow{2}{*}{ Item } & \multicolumn{3}{|c|}{ Groups } \\
\cline { 2 - 4 } & G1 & G2 & G3 \\
\hline Hemoglobin $(\mathrm{Hb}), \mathrm{g} / \mathrm{dl}$ & $10.80 \pm 0.10^{\mathrm{b}}$ & $11.43 \pm 0.07^{\mathrm{a}}$ & $11.20 \pm 0.21^{\mathrm{a}}$ \\
\hline Red blood cell $(\mathrm{RBC} \mathrm{s}), 10^{6} / \mathrm{\mu l}$ & $12.07 \pm 0.28$ & $12.40 \pm 0.25$ & $12.23 \pm 0.27$ \\
\hline Glucose, $\mathrm{mg} / \mathrm{dl}$ & $68.67 \pm 0.88^{\mathrm{b}}$ & $72.00 \pm 1.15^{\mathrm{ab}}$ & $73.33 \pm 1.45^{\mathrm{a}}$ \\
\hline Cholesterol, $\mathrm{mg} / \mathrm{dl}$ & $70.33 \pm 1.76$ & $68.00 \pm 2.08$ & $67.67 \pm 2.91$ \\
\hline Total protein (TP), g/dl & $6.62 \pm 0.04$ & $6.57 \pm 0.04$ & $6.50 \pm 0.08$ \\
\hline Urea-N, mg/dl & $17.87 \pm 0.41^{\mathrm{a}}$ & $16.43 \pm 0.30^{\mathrm{b}}$ & $16.27 \pm 0.15^{\mathrm{b}}$ \\
\hline Creatinine, mg/dl & $0.93 \pm 0.06$ & $0.90 \pm 0.06$ & $0.87 \pm 0.08$ \\
\hline Calcium, $\mathrm{mg} / \mathrm{dl}$ & $10.80 \pm 0.25$ & $10.97 \pm 0.12$ & $10.93 \pm 0.15$ \\
\hline Phosphorus ( inorganic), mg/dl & $5.40 \pm 0.10^{\mathrm{b}}$ & $5.60 \pm 0.12^{\mathrm{a}}$ & $5.63 \pm 0.12^{\mathrm{a}}$ \\
\hline AST, u/l & $75.67 \pm 2.40$ & $72.33 \pm 2.33$ & $75.00 \pm 3.21$ \\
\hline ALT, u/l & $22.00 \pm 1.04$ & $20.33 \pm 0.73$ & $21.00 \pm 1.04$ \\
\hline ALP, $\mathrm{u} / \mathrm{l}$ & $112 \pm 4.67$ & $108 \pm 3.71$ & $105 \pm 4.91$ \\
\hline
\end{tabular}


El-Emam G. I. et al.

Table 6. Effect of experimental rations on milk composition and its quality by dairy Zaraibi goats.

\begin{tabular}{|l|c|c|c|}
\hline \multirow{2}{*}{ Item } & \multicolumn{3}{|c|}{ Groups } \\
\cline { 2 - 4 } & $\mathbf{G 1}$ & $\mathbf{G}$ & $\mathbf{G}$ \\
\hline Total milk yield ,kg/h & $131 \pm 5.21^{\mathrm{b}}$ & $163 \pm 8.54^{\mathrm{a}}$ & $151 \pm 2.90^{\mathrm{a}}$ \\
\hline Average milk yield ,kg/h/d & $1.339 \pm 0.05^{\mathrm{b}}$ & $1.601 \pm 0.09^{\mathrm{a}}$ & $1.550 \pm 0.03^{\mathrm{a}}$ \\
\hline Milk composition: & $3.60 \pm 0.08$ & $3.48 \pm 0.04$ & $3.53 \pm 0.04$ \\
\hline Fat,\% & $2.94 \pm 0.03$ & $2.92 \pm 0.03$ & $2.90 \pm 0.04$ \\
\hline Protein,\% & $4.53 \pm 0.02$ & $4.57 \pm 0.03$ & $4.55 \pm 0.03$ \\
\hline Lactose,\% & $11.78 \pm 0.09$ & $11.69 \pm 0.02$ & $11.70 \pm 0.03$ \\
\hline Total solids,\% & $8.18 \pm 0.04$ & $8.21 \pm 0.04$ & $8.16 \pm 0.06$ \\
\hline Solids non fat (SNF),\% & $0.71 \pm 0.003$ & $0.72 \pm 0.005$ & $0.71 \pm 0.007$ \\
\hline Ash,\% & $470 \pm 12.21^{\mathrm{b}}$ & $568 \pm 25.16^{\mathrm{a}}$ & $534 \pm 7.31^{\mathrm{a}}$ \\
\hline Average fat yield, g/h/d & $384 \pm 14.18^{\mathrm{b}}$ & $478 \pm 28.06^{\mathrm{a}}$ & $440 \pm 13.84^{\mathrm{a}}$ \\
\hline Average protein yield, g/h/d &
\end{tabular}

Means in the same row with different superscripts differ significantly at $P<0.05$.

Table 7. Feed conversion of lactating Zaraibi does fed experimental rations.

\begin{tabular}{|l|c|c|c|}
\hline \multirow{2}{*}{ Item } & \multicolumn{3}{|c|}{ Groups } \\
\cline { 2 - 4 } & G1 & G2 & G3 \\
\hline No . of Zaraibi goats & 6 & 6 & 6 \\
\hline Average body weight, $\mathrm{kg}$ & 39.75 & 40.21 & 40.13 \\
\hline Metabolic body size, $^{0.75}$ & 15.83 & 15.97 & 15.94 \\
\hline Average feed intake during the experimental periods : & 549 & 545 \\
\hline CFM, g/h/d & 535 & 894 & 867 \\
\hline Silage, g/h/d & 813 & 1443 & 1412 \\
\hline Total DM intake, g/h/d & 1348 & 200.0 & 191.0 \\
\hline CP intake, g/h/d & 194.0 & 1601 & 1550 \\
\hline Average milk yield, g/h/d & 1339 & \multicolumn{3}{|l}{} \\
\hline Feed conversion : & 1.01 & 0.901 & 0.911 \\
\hline Kg DM / kg milk & 0.145 & 0.125 & 0.123 \\
\hline Kg CP / kg milk & \multicolumn{3}{|l}{} \\
\hline
\end{tabular}

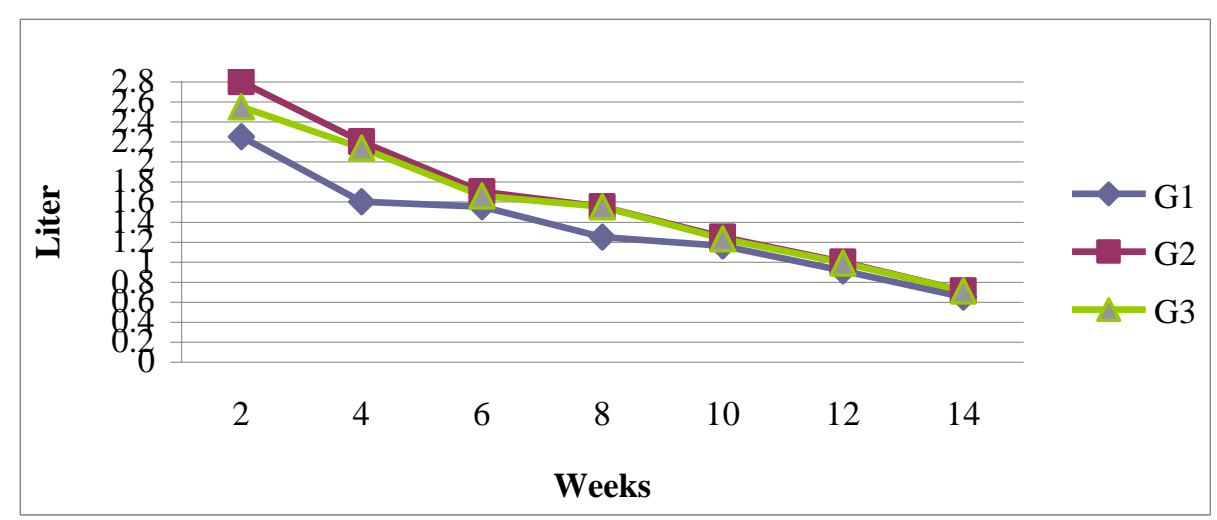

Fig. 1: Average daily milk yield, measured biweekly, for different tested diets. 


\section{Conclusion}

It could be concluded that using silage mixtures (berseem- barely and berseem- millet $x$ napier grass hybrid) in feeding lactating Zaraibi goats had positive effect not only on improving feed intake and ruminal parameters, but also on improving the milk production reflected on better efficiency of feed utilization and performance generally.

\section{REFERENCES}

Ahmed, M. E. and M.E. El-Kholany (2012). Productive performance, some rumen parameters and blood profile of Zaraibi goats fed rations supplemented with chufa tubers during late pregnancy and suckling periods.J.Animal and poultry Prod.,Mansoura Univ.,Vol.3(12):537- 555

Ahmed, M. E., A.M. Abdelhamid, F.F. Abou Ammou, E.S. Soliman, N.M. ElKholy and E. I. Shehata (2001). Response of milk production of Zaraibi goats to feeding silage containing different levels of teosinte and kochia. Egyptian J. Nutrition and Feeds, 4: 141.

Ahmed M.E., E.I. Shehata, F.F. Abou Ammou, A.M. Abdel-Gawad, and K.M. Aiad. (2008). Milk production, feed conversion rate and reproduction of Zaraibi goat in response to bacterial feed additive during late pregnancy and lactation. Egypt. J. Anim. Prod., 45: 189.

Ahmed M.E., E.I. Shehata, M. E. El-Kholany, G.I. El-Emam, E.I. Khalifa and H. Bahery (2013). Productive performance of Zaraibi goats fed berseem and/or triticale silage. The $4^{\text {th }}$ Scientific Conference of Animal Production Research Institute, 184:192.

A.O.A.C. (1995). Official Methods of Analysis (16 th Edit). Association of Official Analytical Chemists, Washington, D.C., USA.

Conway, E.F.(1957). Micro diffusion Analysis and Volumetric Error. Rev. Ed. Lock Wood, London.

Duncan, D. (1955). Multiple ranges and multiple F-test. Biometrics,11: 1.

El-Kholany, M. M (2004). Evaluation of some new green fodder for Farm animals. Ph.D. Thesis Fac. of Agric, Mansoura Univ.

Eweedah, N.M., N.S. Saleh, E.M. Abd el-Raouf, M.M. Bendary and M. Maree (2007). Evaluation of reed (Arundo domax, L.) plants for feeding lactating buffaloes. Egyptian J. Nutrition and Feeds., 10 (2) (special Issue), 15.

Gabr, A.A.,A.Z. Mehrez, E.S.M. Soliman and M. El-Kholany (1999). Response of lactating goats to diets containing reed grass (Aroundo domax L.) versus sorghum plants, Egyptian J. Nutrition and Feeds , 2 ( special Issue), 297.

Gabra, M.A., A.E.M. Khinizy and M.R.M. Moustafa (1991). Chemical and nutritional evaluation of some varieties of sorghum sown singly or intercropped with cowpea. J. Agric. Sci. Mansoura Univ., 16:2807.

Haggag, M. El-H., E. S. Soliman, E.M. Gaafer and M.I. Salim (2000). Effect of phosphate fertilizer levels and seeding rates on yield, quality and nutritional evaluation of sesbania forage by goats. J. Agric. Sci. Mansoura Univ., 25 (7) : 3901. 


\section{El-Emam G. l. et al.}

Haggag, M. El-H., E. S. Soliman and M.E. Ahmed (2002). Triticale forage as a feed for sheep. Proc., $1^{\text {st }}$ Ann. Sc. Conf. Anim. and Fish Prod, P. 7783. Mansoura, Sep,.

Ibrahim, F.A., E.S, Soliman, A. A. Abd El-Hamid and M. E. Ahmed. (2012). Growth performance and feed utilization efficiency of Rahmani lambs fed some legume and /or grass silages. Egyptian J. of Sheep and Goats Sciences, 7 (2): 1- 10.

Ibrahim, F.A , M. E. Ahmed and A. S. Soliman (2008). Cultivation and evaluation of some green forage mixture and its utilization in feeding of lactating zaraibi goats. Egyptian J. Nutrition and Feeds, 11 (2): 329.

Jain, N.C. (1986). Veterinary Hematology. $4^{\text {th }}$ Ed., Lea \& Febiger. Pheladelphia.

Keneko. I.H. (1989). Chemical Biochemistry of Animals. $4^{\text {th }}$ ED. Academic Press, Inc USA.

Khinizy, A.E.M., M.K., Hathout, W.H. Abdel-Malik, S.I. Hafez and P.A. Aspila (1997). Evaluation of some summer forages cultivated in new reclaimed sandy soil in Egypt. J. Agric. Sci. Mansoura Univ., 22 (8) $: 2565$.

Ling, E.R. (1963). A Text Book of Dairy Chemistry. 3rd Ed. Chapman and Hall Ltd., London.

McCartney, D. H. and A. S. Vaage (1994) . Comparative yield and feeding value of barley oat and triticale silages. Can. J. Anim. Sci. p: 91-96.

Mooso, G. D. and W.F. Wedin (1990). Yield dynamics of canopy components in alfalfa grass mixtures. Agric. J., 82 (4): 696.

NRC (1981).Nutrient Requirements of Domestic Animals. Nutrient Requirements of Goats. National Research Council, Washington, D.C. USA of Official Analytical Chemists, Washington, D.C., USA

SAS Institute (2003). SAS/STATR User's Guide: statistics. Ver. 9.1, SAS Institute Inc., Cary, NC, USA.

Schultz, T.A. and E. Schultz (1970). Estimation of rumen microbial nitrogen by three analytical methods. J. Dairy Sci , 53:781.

Shehata E.I; M.E. Ahmed, A.M. Abdelhamid, Faten F. Abou Ammou, and M. $\mathrm{El}-\mathrm{H}$. Haggag (2001) Comparative nutritive values of silage ration containing different level of teosinte and kochia. Egyptian J. Nutrition and Feeds, (4):129.

Soliman, E. S. and M. El-H. Haggag (2002). Effect of feeding green forage mixtures of sesbania and teosinte instead of concentrate feed mixture on lactating goats. Egypt. J. Appl. Sci.., 17 (5): 31-42.

Soliman, E. S., A. E. M. Khinizy, Bahira K. Mohammed and M. El-H. Haggag (1997). Studies on using Sesbania and Teosinte forage in feeding of growing Zaraibi goats. Egypt. J. Appl. Sci., 12 (50:63- 74.

Soliman, A. A., M. E. Ahmed, Faten. F. Abou Ammou, E. I. Shehata, M. K. Abou Elmaged, S. A. Tawfik and M. A. Shebl ( 2010). Impact of some feed additives on Zaraibi goats performance and blood profile fed aflatoxins contaminated diets. American- Eurasian J. Agric. and Environ. Sci., 7 (1) : 80. 
Van Soest, P. J. (1996 ) . Environment and forage quality. Proc. Cornell Nut. Conf. Feed Manuf. P 1 Cornell Univ., Ithaca, NY.

Warner, A.C.I. (1964). Production of volatile fatty acids in the rumen, methods of measurements. Nutr. Abst. \& Rev., 34: 339.

Zeidan, E. M. and H. G. M. Geweifel (1997). Effect of propagation method and cutting frequency on forage yield and quality of Napier grass and its hexaploid hybrid with pearl millet. Egypt. J. Appl. Sci., 12 (3): 29-52.

إنتاج اللبن وبعض قياسات سـائل الكرش وكفاءة التحويل الغذائي للمـاعز الزرايبي التئي

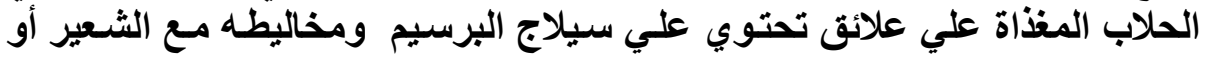

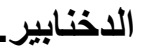

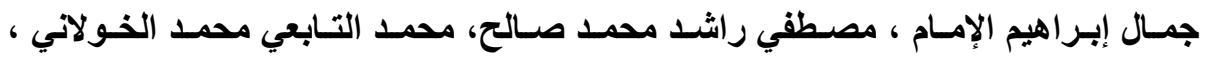

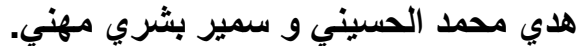

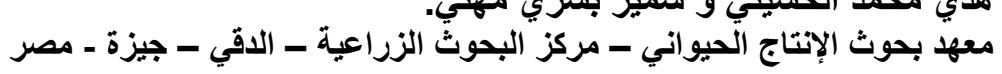

أجري هذا البحث لدر اسة تأثتير استخدام سيلاج البرسيم ومخاليطها مع الثنعير أو الدخنابير في علائق الماعز

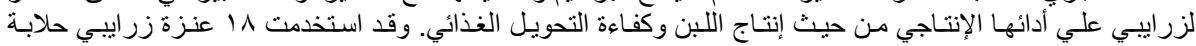

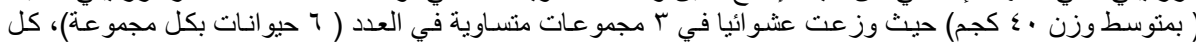

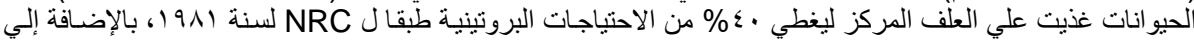

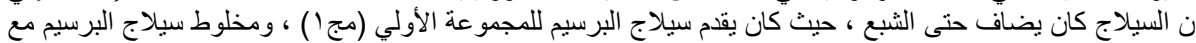

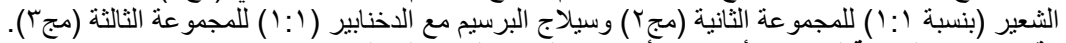

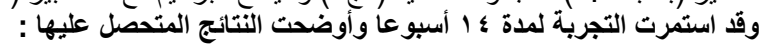

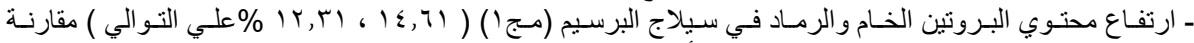

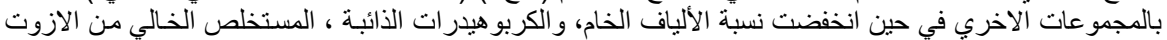

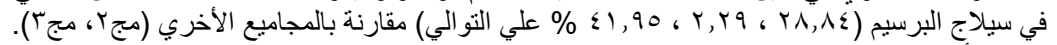

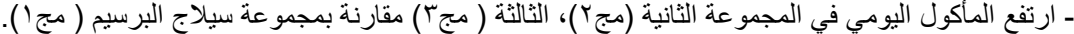

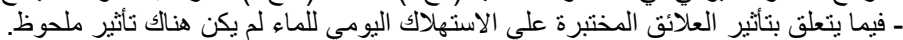

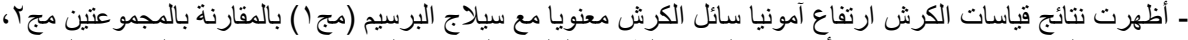

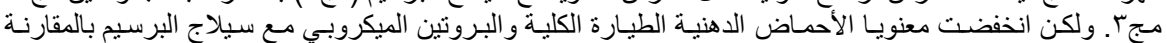

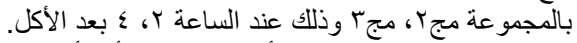

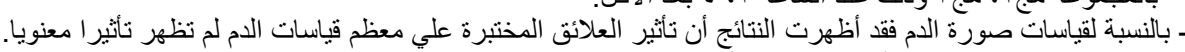

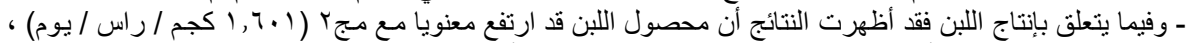

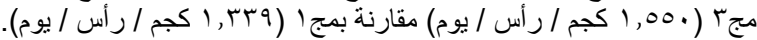

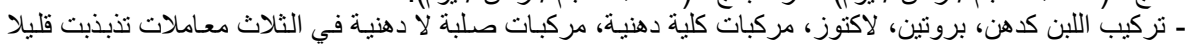

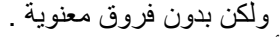

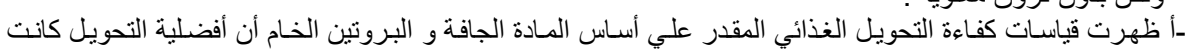

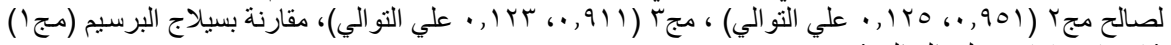

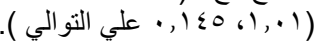

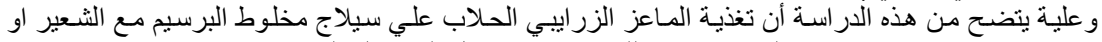
الدخنابير ( بنسبة (: () قد حسنت بيئة الكرش، إنتاج اللبن، وكفاءة تحويل الغذاء إلي لبن.

كلية الزراعة - جامعة المنصورة مركز البحوث الزراعية

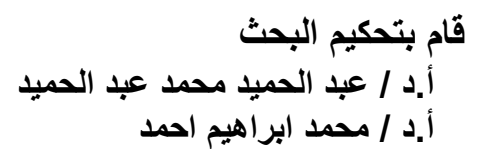

قام بتحكيم البحث أ.د / محمد ابراهيم احمد الدمد 
EI-Emam G. I. et al. 